\title{
Vietnamese university students' perspective on Peter Pan Syndrome
}

\author{
Research Article
}

Hanh My Mai', Thanh Minh Vo', Xuan Thi Thanh Nguyen', Vinh-Long Tran-Chi'1,2,*

1. Faculty of Psychology, Ho Chi Minh City University of Education, Ho Chi Minh City, Vietnam.

2. Faculty of Education, Thu Dau Mot University, Thu Dau Mot City, Binh Duong Province, Vietnam.

\begin{abstract}
An increasing number of people, especially university students, are presenting Peter Pan Syndrome in society. Peter Pan Syndrome is a concept used to characterize the person who refuses to comply with the characteristics of the adult when reaching adulthood. The people with Peter Pan Syndrome are immature in emotion, behavior, and cognition. The main objective is to investigate the perception of Peter Pan Syndrome and the level of Peter Pan Syndrome among university students. Convenience sampling was used to collect data from 400 undergraduate students (186 males and 214 females) from three universities in Vietnam. Descriptive and inferential statistics were used to analyze the data. The results revealed that the manifestations of Peter Pan Syndrome in students in three dimensions of emotion, behavior, and cognition. This study contributes to the general discussion underway about the definition of Peter Pan Syndrome and the symptoms of Peter Pan Syndrome. Future research should carefully consider the potential effects of Peter Pan Syndrome among undergraduate students to assist families and educators in developing appropriate education and coping strategies.
\end{abstract}

Key Words: Peter Pan Syndrome, University students, Emotion, Behavior, Cognition.

\section{Introduction}

Many researchers have studied the maturity of people in recent years, especially among university students, which has piqued the interest of many psychologists. The term "Emerging adulthood" was characterized by no longer adolescents but have not yet become adults or between puberty and adulthood (1). According to the study of Wider, Low (2), adulthood is an important period in the human life span, change in behaviors and perceptions of themselves and others. The transition to adulthood developed by Wall, Law (3) involved changes in biological or cognitive dimensions and the establishment of goal-directed and social relationships. Psychological determiners were considered to be important in the transition to adulthood (4). The manifestation of students delaying their transition into adulthood has been a common issue today. The concept of people who do not want to grow up was called Peter Pan Syndrome. There have a large number of researchers has studied this subject, including Peter Pan Syndrome in marriage (5); man's Peter Pan Syndrome with adolescent mothers' intimate relationships (6); Peter Pan Syndrome among mountain climbers (7); Peter Pan Syndrome in churches (8); the

\section{* Corresponding Author:}

\section{Vinh-Long Tran-Chi}

Faculty of Psychology, Ho Chi Minh City

University of Education, Ho Chi Minh City,

Vietnam and Faculty of Education, Thu Dau Mot

University, Binh Duong Province, Vietnam

Email Id: longtcv@hcmue.edu.vn phenomenon of Peter Pan Syndrome in adult man (9); Peter Pan Syndrome among anorexia nervosa patients (10).

The study of Kiley (11) has suggested that the concept "Peter Pan Syndrome" has recently gained popularity as a metaphor for "men who have never grown up". Some previous studies revealed the manifestation of a person who has Peter Pan Syndrome that person who refuse to comply with the characteristics of the adult when reaching adulthood Kiley (11); they are unable to cope with adult emotions and responsibilities, difficulty in social and professional relationships and behave childish characterized $(9,12)$; staying a child and sustaining the parents' protection (13), postponing between childhood and adulthood (10). Quadrio (1982) described the concept "Peter Pan Syndrome" as a man married who is immature, narcissistic, and unfaithful. The syndrome can appear among young men such as undergraduate students, who are dynamic in school activities and independent from their parents. However, they tend to resist committing to long-term relationships. In addition, the term of "Peter Pan Syndrome" described people who yearn for independence, are brave in facing danger. However, they are panic-stricken by maturity, suffer from narcissism, and unable to create mature interpersonal relationships with the opposite sex in daily life (14). Didevar conducted a previous study revealed that Peter Pan Syndrome is a disorder in which an individual has the physical appearance of an adult but retains the mental, emotional and psychological outlook of a child. They tend to avoid taking responsibilities and competencies of adulthood. In today, Peter Pan 
Syndrome has become a common topic of discussion. People are becoming increasingly immature, preferring to satisfy their own needs for fulfillment rather than putting in an effort to create long-term relationships with others (7).

Several scientific studies have been conducted on the origins of Peter Pan Syndrome, including family environment, parenting styles, stresses in modern society. An individual has been living in parental unhappiness such as parents' dissatisfaction with their marriage and themselves, a lack of emotional warmth and sharing..., all of which affect an individual in different ways. In addition, people between the ages of from 18 to 22 must tackle and address magical thinking and marginal ego development. Those people still are trapped in Peter Pan Syndrome for an extended period if they do not overcome this process (11). According to Ortega (15), the factor affecting Peter Pan Syndrome among young people is the parents' overprotection or scare of loneliness. The people have not developed the necessary skills to confront life. Children with overcontrolling or intrusive parenting may be less able to manage emotions, orient their behaviors in the school setting, resulting in greater maladjustment across social, academic, and emotional domains (16).

The study of Kiley (11) revealed that there are six symptoms and social stress which act as domination the emotion, behavior, perception, belief systems, spirits of individuals suffering from Peter Pan Syndrome including irresponsibility, anxiety, loneliness, sex role conflict, narcissism and chauvinism, a piratical lifestyle. Individuals fail to learn basic self-care skills, prioritize issues, and care for themselves due to their parents' overprotection. They are irresponsible and unconscionable foul deeds. Besides, they easily blame others for their mistakes and break promises. They desperately want to find a place where they belong. They need friends and they are afraid of being alone, but they are extremely self-centered. However, people have difficulties in interpersonal relationships because of their desire to seek perfection. They have poor selfconfidence.

Moreover, people with Peter Pan syndrome have magical thinking that takes them away from reality. They find it difficult to express their emotions and cope with life's disappointments, making them vulnerable. In order to defend themselves from this vulnerability, they prefer to confront all with "I don't care" attitude as a defense against criticism. They prefer to resist commitment relationships in loving relationships. According to the study of Quadrio (5), people with Peter Pan Syndrome tend to have instability in their career issues, same as their loving relationships. They desperately want a job, but they refuse to work for it because they don't take responsibility for their actions. In addition, the research of Dalla, Marchetti (6) indicated that husbands with Peter Pan Syndrome were unable to establish a close relationship with their wives, was not emotionally involved in the relationship, and refused to work. In Vietnam, few scientific studies have been conducted about Peter Pan Syndrome, especially with the participants being university students.
However, several studies have concentrated on the criteria to evaluate personal development in social work among undergraduate students so far such as (17-19).

Based on the findings of previous studies and psychologists' viewings, our research conduct to study Peter Pan Syndrome with symptoms including difficulty expressing emotions; postponing decision making; difficulty in forming and maintaining relationships with friends and lovers, irresponsibility, blaming others, without pushing themselves, staying motivated, and losing interest at work; avoiding commitment; feelings of anger and guilt with parents and want to be closer to parents. This paper aims to fill this gap by exploring and measuring university students' perceptions of Peter Pan Syndrome in Ho Chi Minh, Vietnam.

\section{Methods \\ Participants}

Participants were selected randomly from threemember universities in Ho Chi Minh City, Vietnam. All participants provided informed consent after receiving an explanation of the purpose of the research. The survey instrument was distributed to 450 undergraduate students, of which 400 questionnaires returned, including males accounted for $46.5 \%(\mathrm{n}=186)$, and females accounted for $53.5 \%(n=214)$.

Table 1: An overview of the survey participants

\begin{tabular}{|c|c|c|c|}
\hline & & $\mathbf{n}$ & $\%$ \\
\hline \multirow{2}{*}{ Gender } & Male & 186 & 46.5 \\
\hline & Female & 214 & 53.5 \\
\hline \multirow{3}{*}{ School } & HUTECH University & 122 & 30.5 \\
\hline & Nguyen Tat Thanh University & 124 & 31.0 \\
\hline & $\begin{array}{l}\text { Ho Chi Minh City University } \\
\text { of Education }\end{array}$ & 154 & 38.5 \\
\hline \multirow{4}{*}{$\begin{array}{l}\text { Academic } \\
\text { Year }\end{array}$} & Freshman & 53 & 13.3 \\
\hline & Sophomore & 172 & 43.0 \\
\hline & Junior & 147 & 36.8 \\
\hline & Senior & 28 & 7.0 \\
\hline \multirow{5}{*}{ GPA } & Outstanding & 36 & 9.0 \\
\hline & Very good & 52 & 13.0 \\
\hline & Good & 227 & 56.8 \\
\hline & Average & 78 & 19.5 \\
\hline & Pass & 7 & 1.8 \\
\hline \multirow{4}{*}{ Birth Order } & Oldest child & 172 & 43.0 \\
\hline & Middle child & 60 & 15.0 \\
\hline & Youngest child & 121 & 30.3 \\
\hline & Only child & 47 & 11.8 \\
\hline
\end{tabular}

\section{Measurement}

The questionnaire was designed to survey university students from the universities in Ho Chi Minh City, Vietnam. First, social-demographic items were introduced in the questionnaire. Then, university students were measured by the questionnaire about emotion, cognition, and behavior. The instrument consists of four-part involves in: Part I containing 
questions about the university students' perception of the problems relating to their maturity; Part II containing questions about the manifestation of Peter Pan Syndrome in university students in the dimension of cognition; Part III containing questions about the manifestation of Peter Pan Syndrome in university students in emotional dimension; Part IV containing questions about the manifestation of Peter Pan Syndrome in university students in the dimension of behavior. Then, students were interviewed to collect data.

\section{Procedures}

Participants were provided informed consent and an explanation of the purpose of the study before participation. In the beginning, participants are required to complete the General Information form, including the school's name, school year, gender, GPA, birth order. Subsequently, the instructions of the scale were introduced to undergraduate students to understand the questionnaire.

\section{Results}

As is shown in Table 2 below, Peter Pan Syndrome manifests cognitively in university students.

Table 2: The manifestation of Peter Pan Syndrome in university students in the cognitive dimension

\begin{tabular}{|c|c|c|c|c|c|}
\hline & \multicolumn{5}{|c|}{ Level } \\
\hline & $\begin{array}{l}\text { Totally } \\
\text { Agree }\end{array}$ & Agree & Neutral & Disagree & $\begin{array}{c}\text { Totally } \\
\text { Disagree }\end{array}$ \\
\hline $\begin{array}{l}\text { Thinking that living for the day will be okay without thinking of } \\
\text { tomorrow. }\end{array}$ & 5.0 & 6.0 & 10.5 & 42.5 & 36.0 \\
\hline $\begin{array}{l}\text { Thinking that being free, footloose, and fancy-free will be better than } \\
\text { having a permanent job. }\end{array}$ & 4.8 & 14.5 & 24.5 & 39.3 & 17.0 \\
\hline Thinking that one must have big dreams in life. & 10.8 & 39.5 & 25.5 & 18.0 & 6.3 \\
\hline $\begin{array}{l}\text { Thinking that something goes wrong, just be quiet in the discussion, } \\
\text { leave home, or shut myself in the room. }\end{array}$ & 2.3 & 5.8 & 11.0 & 55.0 & 26.0 \\
\hline $\begin{array}{l}\text { Thinking that learning is unimportant; hence they drop out of school } \\
\text { easily. }\end{array}$ & 0.8 & 10.0 & 5.5 & 49.3 & 34.5 \\
\hline $\begin{array}{l}\text { Thinking that some subjects were failed causes me to pay more attention } \\
\text { to learning. }\end{array}$ & 3.5 & 9.5 & 7.5 & 37.0 & 42.5 \\
\hline Thinking that studying is the most boring things I have to. & 2.3 & 4.3 & 14.5 & 47.3 & 31.8 \\
\hline Thinking that the purpose of learning is unnecessary. & 2.5 & 4.5 & 10.3 & 52.3 & 30.5 \\
\hline Thinking that the promise for people does not need to make. & 1.0 & 5.5 & 4.8 & 39.0 & 49.8 \\
\hline $\begin{array}{l}\text { Thinking that this life does not necessarily be a long-term commitment in } \\
\text { relationships with friends and lovers. }\end{array}$ & 2.3 & 11.8 & 13.3 & 39.5 & 33.3 \\
\hline $\begin{array}{l}\text { Thinking that there is no need to listen to those who have some difference } \\
\text { of opinion. }\end{array}$ & 2.0 & 5.5 & 17.5 & 49.0 & 26.0 \\
\hline Thinking that hurting and retaliating against others are common. & 1.5 & 4.3 & 14.0 & 39.8 & 40.5 \\
\hline Thinking that centre of attention is the important thing. & 2.0 & 11.8 & 25.8 & 42.3 & 18.3 \\
\hline Thinking that money can buy love. & 2.3 & 9.3 & 14.5 & 35.3 & 38.8 \\
\hline The partner must indulge and take care of me from little things. & 4.0 & 12.5 & 15.5 & 44.8 & 23.3 \\
\hline Thinking that the lover must obey and praise me. & 2.8 & 7.5 & 17.5 & 48.0 & 24.3 \\
\hline $\begin{array}{l}\text { Thinking about whatever happened, I always put myself first in any } \\
\text { situation. }\end{array}$ & 7.8 & 14.8 & 27.8 & 35.8 & 14.0 \\
\hline
\end{tabular}

The findings in Table 2 shows $10.8 \%$ that students totally agreed and $39.5 \%$ of students agree with the view "Thinking that one must have big dreams in life"; followed by $7.8 \%$ of students totally agreed and $14.8 \%$ students agreed with the view "Thinking whatever happened, I always put myself first in any situation".

Table 3: The manifestation of Peter Pan Syndrome in university students in the emotional dimension

Level

\begin{tabular}{|l|c|c|c|c|c|}
\hline & Very Frequently & Frequently & Occasionally & Rarely & Never \\
\hline I usually feel keyed up and scared without knowing the aetiology. & 5.8 & 10.3 & 47.3 & 28.3 & 8.5 \\
\hline Lack of self-confidence. & 7.5 & 23.0 & 48.5 & 18.5 & 2.5 \\
\hline I usually scold myself. & 5.8 & 22.3 & 40.0 & 25.5 & 6.5 \\
\hline It is difficult to control emotions and emotional explosions. & 10.3 & 13.0 & 38.3 & 32.5 & 6.0 \\
\hline It is challenging to express emotions with others. & 10.5 & 22.5 & 37.3 & 22.8 & 7.0 \\
\hline Worrying about the ability to concentrate. & 7.5 & 23.5 & 37.8 & 25.5 & 5.8 \\
\hline Fear and difficulty talking to high-status people. & 6.0 & 16.3 & 32.5 & 33.3 & 12.0 \\
\hline $\begin{array}{l}\text { Lack of self-confidence in decision-making if there are no parents' } \\
\text { agreement/consent. }\end{array}$ & 4.3 & 7.3 & 27.0 & 36.0 & 25.5 \\
\hline
\end{tabular}


Feeling keyed up when being with family.

Feeling unhappy because of without getting along with my parents.

I am always comfortable and happy with others but lonely deep inside.

When no one besides me is sad, so I want someone by my side. They communicate widely, but there are no close friends to confide in and open my heart.

Be unable to get along with others of the same age and sex.

Doing some activities to relieve sadness.

Be unhappy with seeing me as a family member.

\begin{tabular}{|c|c|c|c|c|}
\hline 0.8 & 3.0 & 12.0 & 16.0 & 68.3 \\
\hline 2.5 & 7.8 & 15.5 & 18.3 & 56.0 \\
\hline 17.0 & 17.8 & 35.0 & 19.5 & 10.8 \\
\hline 11.3 & 18.3 & 29.5 & 23.3 & 17.8 \\
\hline 11.8 & 18.3 & 29.3 & 22.0 & 18.8 \\
\hline 3.3 & 6.8 & 23.3 & 34.5 & 32.3 \\
\hline 14.8 & 19.5 & 32.0 & 22.5 & 11.3 \\
\hline 0.8 & 2.3 & 6.8 & 8.0 & 82.3 \\
\hline
\end{tabular}

Table 3 represents the primary manifestations of students in emotional dimension with three levels ranging from (very frequently to occasionally) as below: "Lack of self-confidence" with 7.5\% (very frequently), $23.0 \%$ (frequently), 48.5\% (occasionally); followed by "It is difficult to express emotions with others" with 10.5\% (very frequently), 22.5\% (frequently), 37.3\% (occasionally); "I am always comfortable and happy with others, but lonely deep inside" with 17.0\% (very frequently), 17.8\% (frequently), 35.0\% (occasionally); "I usually scold myself" with $5.8 \%$ (very frequently), $22.3 \%$ (frequently), 40.0\% (occasionally); "Doing some activities to relieve sadness" with $14.8 \%$ (very frequently), $19.5 \%$ (frequently), 32.0\% (occasionally); "Worrying about the ability to concentrate" with $7.5 \%$ (very frequently), $23.5 \%$ (frequently), $37.8 \%$ (occasionally).

\section{Table 4: The manifestation of Peter Pan Syndrome in university students in self-consciousness dimension} Level

I do not want to be considered a weak person, so I try to be strong all the time.

Proving I am the perfect person.

It is easy to satisfy when others praise me.

\begin{tabular}{|c|c|c|c|c|}
\hline $\begin{array}{c}\text { Very } \\
\text { Frequently }\end{array}$ & Frequently & Occasionally & Rarely & Never \\
\hline 10.3 & 22.5 & 26.3 & 21.0 & 20.0 \\
\hline 3.5 & 8.8 & 27.0 & 31.3 & 29.5 \\
\hline 4.5 & 18.3 & 33.0 & 29.0 & 15.3 \\
\hline 1.8 & 5.3 & 10.5 & 32.0 & 50.5 \\
\hline 2.8 & 3.8 & 18.5 & 36.3 & 38.8 \\
\hline 2.5 & 4.0 & 24.3 & 34.8 & 34.5 \\
\hline 5.5 & 21.8 & 31.5 & 25.0 & 16.3 \\
\hline 10.5 & 8.8 & 24.5 & 28.5 & 27.8 \\
\hline 18.8 & 19.0 & 24.0 & 22.0 & 16.3 \\
\hline 6.8 & 17.0 & 23.5 & 29.0 & 23.8 \\
\hline 18.8 & 20.8 & 23.3 & 22.8 & 14.5 \\
\hline
\end{tabular}

Highly appreciating my job and assuming that other people's job is unimportant.

Do not listen to other people's views when there has some difference of opinion.

I am gifted but others do not appoint me in the important post.

Be unable to identify my strengths and weaknesses.

I do not want to compare myself to others to study.

I am not ashamed of being considered a child.

23.3

22.8

14.5

Doing some activities to relieve sadness.

Table 4 indicates the primary manifestations of students in self -consciousness dimension with three levels ranging from (very frequently to occasionally) as below: "I am not ashamed of being considered a child" with 18.8\% (very frequently), 19.0\% (frequently), 24.0\% (occasionally); followed by "Be unable to identify my strengths and weaknesses" with 5.5\% (very frequently), 21.8\% (frequently), 31.5\% (occasionally); "I do not want to be considered a weak person, so I try to be strong all the time" with $10.3 \%$ (very frequently), 22.5\% (frequently), 26.3\% (occasionally); and "It is easy to satisfy when I am praised by others" with $4.5 \%$ (very frequently), $18.3 \%$ (frequently), $33.0 \%$ (occasionally).

Table 5: The manifestation of Peter Pan Syndrome in university students in dimension of worldviews and belief systems

Worldviews and belief systems

I need to express self-beliefs in life.

Setting clear goals and making life plans.

Keeping our self-esteem always.

Calculating productivity and efficiency (financial management, expenditure

organization).

Dare to think, dare to act, and dare to take risks.

Striving for a permanent job and promotion in the future.

\begin{tabular}{|c|c|c|c|}
\multicolumn{2}{|c|}{ Right } & \multicolumn{2}{c|}{ Wrong } \\
\hline $\mathrm{n}$ & $\%$ & $\mathrm{n}$ & $\%$ \\
\hline 382 & $95.5 \%$ & 18 & $4.5 \%$ \\
\hline 376 & $94 \%$ & 24 & $6.0 \%$ \\
\hline 347 & $86.8 \%$ & 53 & $13.3 \%$ \\
\hline 319 & $79.8 \%$ & 81 & $20.3 \%$ \\
\hline 329 & $82.3 \%$ & 71 & $17.8 \%$ \\
\hline 371 & $92.8 \%$ & 29 & $7.3 \%$ \\
\hline 350 & $87.5 \%$ & 50 & $12.5 \%$ \\
\hline
\end{tabular}

Be active and positive to learn more soft skills, computer skills, and foreign languages.

Table 5 represents that $20.3 \%$ of students supposed the view of "Calculating productivity and efficiency

(financial management, expenditure organization)" was wrong. With $17.8 \%$ of university students supposed that the 
view of "Dare to think, dare to act, and dare to take risks", 13.3\% of "Keeping our self-esteem always", 12.5\% of "Be active and positive to learn more soft skills, computer skills, and foreign languages" was wrong.

Table 6: The manifestation of Peter Pan Syndrome in university students in spirit dimension

\begin{tabular}{|c|c|c|c|c|c|}
\hline & \multicolumn{5}{|c|}{ Level } \\
\hline & $\begin{array}{c}\text { Very } \\
\text { Frequently }\end{array}$ & Frequently & Occasionally & Rarely & Never \\
\hline I was constantly immersed in my unusual thoughts. & 11.0 & 20.5 & 29.8 & 26.3 & 12.5 \\
\hline $\begin{array}{l}\text { Impulsive behavior and hard to control leading to extreme words and } \\
\text { actions. }\end{array}$ & 4.0 & 12.5 & 28.3 & 39.0 & 16.3 \\
\hline I do not want to care about the hard problems at present. & 2.5 & 8.8 & 34.8 & 30.5 & 23.5 \\
\hline It is easy to quit a job or to study when something goes wrong. & 2.5 & 4.8 & 28.0 & 40.8 & 24.0 \\
\hline Even if there are no difficulties in life, I do not want to try anymore. & 1.5 & 8.5 & 20.3 & 33.3 & 36.5 \\
\hline Constantly changing part-time jobs or study groups. & 3.0 & 8.5 & 16.5 & 31.8 & 40.3 \\
\hline I am lazy to do household chores or take care of myself. & 5.0 & 10.5 & 25.0 & 29.8 & 29.8 \\
\hline I do not dare to express my feelings to others. & 8.5 & 19.0 & 31.0 & 25.5 & 16.0 \\
\hline I am reluctant and unable to make decisions when needed. & 6.3 & 20.3 & 34.0 & 26.0 & 13.5 \\
\hline
\end{tabular}

Table 6 indicates the primary manifestations of students in spiritual dimension with three levels ranging from (very frequently to occasionally) as below: "I constantly immersed in my unusual thoughts" with $11.0 \%$ (very frequently), 20.5\% (frequently), 29.8\% (occasionally); followed by "I do not dare to express my feelings to others" with $8.5 \%$ (very frequently), $19.0 \%$ (frequently), $31.0 \%$ (occasionally); and "I am reluctant and unable to make decisions when needed" with $6.3 \%$ (very frequently), $20.3 \%$ (frequently), 34.0\% (occasionally).

\section{Table 7: The manifestation of Peter Pan Syndrome in university students in the dimension of social relationships}

\begin{tabular}{|c|c|c|c|c|c|}
\hline & \multicolumn{5}{|c|}{ Level } \\
\hline & $\begin{array}{c}\text { Very } \\
\text { Frequently }\end{array}$ & Frequently & Occasionally & Rarely & Never \\
\hline Telling a lie in relationships. & 3.5 & 6.0 & 32.5 & 38.3 & 19.8 \\
\hline Refuse to take responsibility in working groups. & 2.0 & 3.8 & 9.5 & 37.5 & 47.3 \\
\hline $\begin{array}{l}\text { Blaming teachers (superiors) when something went wrong in } \\
\text { studying (or working). }\end{array}$ & 0.5 & 5.3 & 17.3 & 31.8 & 45.3 \\
\hline Talking about "male chauvinism" (or vice versa). & 0.5 & 3.5 & 6.3 & 17.3 & 72.5 \\
\hline $\begin{array}{l}\text { I cannot strike up a friendship with people of the opposite sex } \\
\text { because they are bad guys. }\end{array}$ & 1.8 & 9.5 & 16.0 & 25.3 & 47.5 \\
\hline $\begin{array}{l}\text { I want to fall in love quickly when meeting a someone but after that, } \\
\text { I want to break up. }\end{array}$ & 1.5 & 6.5 & 13.8 & 19.5 & 58.8 \\
\hline I easily get angry with comments on myself from others. & 2.8 & 10.3 & 27.5 & 33.3 & 26.3 \\
\hline Relying on the family to take care of money issues. & 15.3 & 28.5 & 28.5 & 14.5 & 13.3 \\
\hline $\begin{array}{l}\text { Spending much time playing games rather than meeting and making } \\
\text { friends. }\end{array}$ & 7.0 & 15.0 & 28.3 & 22.8 & 27.0 \\
\hline $\begin{array}{l}\text { Letting other people, especially parents or the lover, take care of me } \\
\text { from little things. }\end{array}$ & 3.5 & 10.8 & 19.0 & 34.0 & 32.8 \\
\hline Escaping from responsibilities in a romantic relationship. & 1.5 & 3.5 & 16.0 & 26.5 & 52.5 \\
\hline Saying something bad about my friends. & 4.0 & 4.3 & 20.3 & 39.3 & 32.3 \\
\hline $\begin{array}{l}\text { Be willing to give up on relationship with friends if I do not like } \\
\text { anymore. }\end{array}$ & 6.5 & 9.5 & 30.3 & 28.3 & 25.5 \\
\hline Blaming family for my success. & 2.0 & 3.0 & 12.5 & 19.3 & 63.3 \\
\hline Tormenting my family by acting like a child. & 2.3 & 5.5 & 8.0 & 23.5 & 60.8 \\
\hline
\end{tabular}

Table 7 indicates the primary manifestations of students in the dimension of social relationships with three levels ranging from (very frequently to occasionally) as below: "Relying on the family to take care of money issues" with $15.3 \%$ (very frequently), $28.5 \%$ (frequently), and $28.5 \%$ (occasionally).

\section{Discussion}

The study's objectives were to explore the perception of Peter Pan Syndrome and the level of Peter Pan Syndrome among university students. The findings showed that university students' perspective about the cognitive dimension was neutral: they think they must have big dreams in life and always put themselves first in any situation. This is considered that having dreams or goals in life is an important factor for people, especially among undergraduate students. Hence, having appropriate goals is one of the factors affecting students' decisions in the future. This is an aspect in which students should be taught to orient themselves properly. 
The emotional manifestations of Peter Pan Syndrome in students include lack of self-confidence and difficulty expressing emotions with others. I am always comfortable and happy with others, but lonely deep inside with the highest total of three levels of very frequent, frequently, and occasionally were $80 \%$. This finding ties well with previous studies $(11,15)$, which revealed that people with Peter Pan Syndrome found it difficult to express their emotions with others and lack self-confidence.

The manifestation of Peter Pan Syndrome in students in the dimension of behavior include selfconsciousness, worldviews and belief systems; spirit; and social relationships. The findings showed four primary manifestations that students frequently experienced in the self-consciousness dimension, including I do not want to be considered a weak person, so I try to be strong all the time; it is easy to satisfy when others praise me; I cannot identify my own strengths and weaknesses, and I am not ashamed of being considered a child. In addition, the manifestation of Peter Pan Syndrome was obviously shown in students in the dimension of worldviews and belief systems involve in keeping our self-esteem always; calculating productivity and efficiency; care to think, dare to act, and dare to take risks; and be active and positive to learn more soft skills, computer skills, and foreign languages. There are small numbers of students who have yet reached adulthood. They find it difficult to take risks and self-assessment, lack professional interest, and are completely intolerant towards any criticism.

From the results, there were three primary manifestations of Peter Pan Syndrome in university students in spirit dimension ranging from very frequently to occasionally level such as I constantly immersed in my unusual thoughts, I do not have the courage to express my feelings to others, I am reluctant and unable to make decisions when needed. These results line with the previous report Kiley (11) showed that university students with Peter Pan Syndrome had magical thinking. The main manifestation of students in the dimension of social relationships ranging from very frequently to occasionally level was Relying on the family to take care of money issues.

There are several limitations to this approach. One limitation is found in this case: the sampling process from three universities in Ho Chi Minh City might limit the generalization of the results through the other university students. Therefore, the greater number of university students should be expanded to other universities and areas in Vietnam for potential study in the future. Another limitation in this study involves the issue of sampling and self-reported measurements, which also contribute to being biased in the findings and being a cross-sectional analysis that did not allow us to have accurate results. In order to take these limitations into account, a longitudinal study would be much more expedient for better observation of university students' perceptions of Peter Pan Syndrome in different contexts.

\section{Conclusion}

Peter Pan Syndrome is considered a phenomenon that person who refuses to comply with the characteristics of the adult when reaching adulthood. They cannot cope with adult emotions and responsibilities, have difficulty in social and professional relationships and behave childish characterized when they reach adulthood. This symptom was examined in university students. Importantly, our results provide additional information about the symptoms and manifestation of Peter Pan Syndrome in three dimensions: cognition, emotion, and behavior. As a recommendation, this provides a good starting point for further discussion and further research. Future research should consider the potential factors affecting Peter Pan Syndrome in students and investigate the level of this syndrome among university students more carefully. Besides, future research could aim to replicate results in larger sample sizes or in other universities in Vietnam to examine factors influencing Peter Pan Syndrome.

\section{References}

1. Arnett JJ. Are college students adults? Their conceptions of the transition to adulthood. Journal of Adult Development. 1994;1(4):213-224.

2. Wider W, Low SK, Teng HY, Krishnan S, Tan SA, Tan TY. Conceptualization of adulthood among male and female Malaysian undergraduate students: A qualitative approach. Current Psychology. 2021:1-8.

3. Wall JM, Law AK, Zhu M, Munro D, Parada F, Young RA. Understanding goal-directed action in emerging adulthood: Conceptualization and method. Emerging Adulthood. 2016;4(1):30-39.

4. Arnett JJ. Emerging adulthood: The winding road from the late teens through the twenties: Oxford University Press; 2014.

5. Quadrio C. The Peter Pan and Wendy syndrome: A marital dynamic. Australian \& New Zealand Journal of Psychiatry. 1982;16(2):23-28.

6. Dalla RL, Marchetti AM, Sechrest EA, White JL. "All the men here have the Peter Pan syndromethey don't want to grow up": Navajo adolescent mothers' intimate partner relationships-A 15-year perspective. Violence against women. 2010;16(7):743-763.

7. Skorupa A, Draga P. Peter Pan Syndrome Among Mountain Climbers, Close Interpersonal Relationships Aspect. Academic Areas of Scientific Knowledge (pp109-122), Krakow: ALTUS. 2012.

8. Kalu OU. The Peter Pan syndrome: aid and selfhood of the church in Africa. Missiology. 1975;3(1):15-30.

9. Arini DP. Peterpan Syndrome Phenomenon: SelfIdentity Crisis In Forming Intimation In Adult Man. Psikodimensia. 2019;18(2):158-166.

10. Fried R, Vandereycken W. The Peter Pan syndrome: Was James M. Barrie anorexic? International Journal of Eating Disorders. 1989;8(3):369-376. 
11. Kiley D. The Peter Pan syndrome: Men who have never grown up: Dodd, Mead New York; 1983.

12. Kalkan M, Batık MV, Kaya L, Turan M. Peter Pan Syndrome "Men Who Don't Grow": Developing a Scale. Men and Masculinities. 2019:1097184X19874854.

13. Mirkin MP. The Peter Pan Syndrome: Inpatient treatment of adolescent anorexia nervosa. International Journal of Family Therapy. 1985;7(3):205-216.

14. Czapiński J, Kowalczewska J. Psychologia pozytywna: nauka o szczęściu, zdrowiu, sile i cnotach człowieka: Wydaw. Naukowe PWN; 2004.

15. Ortega HR. Overprotecting parents can lead children to develop the so-called 'Peter Pan Syndrome' University of Granada: Department of Personality, Evaluation and Psychological Treatment; 2007 [Available from: https:// canal.ugr.es/prensa-y-comunicacion/science-newsugr/social-economic-and-legal-sciences/ overprotecting-parents-can-lead-children-todevelop-the-socalled-peter-pan-syndrome/.
16. Perry NB, Dollar JM, Calkins SD, Keane SP, Shanahan L. Childhood self-regulation as a mechanism through which early overcontrolling parenting is associated with adjustment in preadolescence. Developmental Psychology. 2018;54(8):1542-1554.

17. Huynh VS. Thử nghiệm một vài biện pháp phát triển một số kĩ năng mềm cho sinh viên Đại học Sư Pham [Experimenting some measures to develop soft skills for students at University of Education]. Ho Chi Minh City University of Education Journal of Science. 2013;50:68-77.

18. Huynh VS. Thực trạng một số kĩ năng mềm của sinh viên Đại học Sư phạm [Education university students' soft skills]. Ho Chi Minh City University of Education Journal of Science. 2012;39:22-28.

19. Nhat HT. Kỹ năng sống của sinh viên Khoa Sư Phạm, trường Đại học An Giang [Undergraduate students' lived-skills at An Giang University of Education]. Journal of Science. 2015;5(1):23-28. 